\title{
SLC8A1 Gene
}

National Cancer Institute

\section{Source}

National Cancer Institute. SLC8A1 Gene. NCI Thesaurus. Code C118227.

This gene is involved in the modulation of cardiac muscle cell relaxation. 